\title{
REVIEW
}

\section{Discerning Clinical Responses in Breast Cancer Based On Molecular Signatures}

\author{
William B. Coleman ${ }^{\star \dagger}$ and Carey K. Anders ${ }^{\dagger \uparrow}$
}

From the Departments of Pathology and Laboratory Medicine* and Medicine, $^{\S}$ the UNC Program in Translational Medicine, ${ }^{\dagger}$ and the UNC Lineberger Comprehensive Cancer Center, ${ }^{\ddagger}$ University of North Carolina School of Medicine, Chapel Hill, North Carolina

Accepted for publication August 3, 2017.

Address correspondence to William B. Coleman, Ph.D., Department of Pathology and Laboratory Medicine, University of North Carolina School of Medicine, Campus Box 7525, 515 Brinkhous-Bullitt Bldg, Chapel Hill, NC 27599. E-mail: william coleman@med.unc.edu.

\begin{abstract}
Breast cancer represents a heterogeneous collection of diseases with disparate clinical behaviors, responses to treatment, and patient outcomes, despite common histopathological features at diagnosis. Examination of molecular signatures of breast cancer (based on complex gene expression patterns) enabled identification of several intrinsic molecular subtypes: luminal A, luminal $B$, human epidermal growth factor receptor 2 enriched, and basal like. The intrinsic subtypes are associated with measures of clinical aggressiveness, but do not perfectly predict patient outcomes. Several molecular signatures have been developed for prediction and prognostication of breast cancer outcomes. This review describes the molecular classification of breast cancer and the use of predictive/prognostic molecular signatures for guiding treatment decisions in breast cancer patients. (Am J Pathol 2017, 187: 2199-2207; http://dx.doi.org/10.1016/j.ajpath.2017.08.002)
\end{abstract}

Breast cancer is well recognized as a heterogeneous collection of neoplastic disorders affecting the breast tissue, with various morphologic presentations and disparate clinical behaviors and outcomes. The challenge for clinicians who treat breast cancer is prediction of which patients will benefit from specific interventions, minimizing overtreatment of patients with indolent disease and providing appropriate treatment for patients with aggressive disease.

Traditional histopathological classification of breast cancers provides a crude guide for therapeutic strategies applied to individual patients. This classification scheme is based on various features of the primary neoplasm, including morphologic appearance and associated pathological features. The most common histological breast cancer subtype is invasive ductal carcinoma (representing $80 \%$ of invasive breast cancers), followed by invasive lobular carcinoma (representing approximately $10 \%$ of invasive breast cancers), with the balance composed of less common histological subtypes, including mucinous, cribriform, micropapillary, papillary, tubular, medullary, metaplastic, and inflammatory carcinomas. ${ }^{1,2}$ Although these histological subtypes are used in the clinical classification of breast cancer in individual patients, it is known that histological appearance alone does not reliably predict clinical behavior of the disease in individual patients. Other pathologic features of breast cancer provide additional insights into probable clinical behavior, including tumor size, cellular features (nuclear grade and proliferation index), nodal status, and invasion of the lymphatics or vasculature. In addition, the expression (or lack of expression) of specific protein markers is associated with aggressiveness of disease, in particular hormone receptor status [expression of estrogen receptor (ER) and progesterone receptor] and human epidermal growth factor receptor 2 (HER2). ${ }^{3}$ On the basis of

Supported by the UNC Lineberger Comprehensive Cancer Center (W.B.C.), the UNC Center for Nanotechology Excellence (W.B.C.), the UNC Department of Pathology and Laboratory Medicine (W.B.C.), Novartis (C.K.A.), Sanofi (C.K.A.), toBBB (C.K.A.), GERON (C.K.A.), Angiochem (C.K.A.), Merrimack (C.K.A.), PUMA (C.K.A.), Lily (C.K.A.), Merck (C.K.A.), Oncothyreon (C.K.A.), Cascadian (C.K.A.), Nektar (C.K.A.), and Tesaro (C.K.A.).

Disclosures: C.K.A. serves in an uncompensated advisory role to Novartis, Sanofi, toBBB, GERON, Angiochem, Merrimack, Lily, Genentech, Nektar, and Kadmon, related to various breast cancer clinical trials.

This article is part of a review series on next-generation breast cancer omics. 
these clinical characteristics, breast cancer presents as several distinct entities, but none of these accurately predicts disease aggressiveness, responses to treatment, likelihood of recurrence or metastasis, or long-term patient outcomes.

The extent of heterogeneity among breast cancers was not fully realized until transcriptomic approaches began to characterize molecular signatures based on gene expression patterns. ${ }^{4-6}$ Early molecular classification of breast cancer was achieved using microarrays to interrogate concurrent gene expression patterns across a large number of transcripts. ${ }^{4-6}$ Subsequently, breast cancer molecular subtypes were shown to be associated with distinct clinical outcomes, ${ }^{7}$ to be useful in patient prognositication, ${ }^{8}$ and to predict responses to neoadjuvant chemotherapy. ${ }^{9}$ These studies (and more recent investigations) have improved our understanding of the biology of breast cancer subtypes, the extent and nature of breast cancer heterogeneity and diversity, and how molecular classification of breast cancer in individual patients might be used in the clinic.

Since the first recognition of intrinsic subtypes among breast cancers ${ }^{10}$ several methods and approaches have been used to subclassify breast cancers and/or to prognosticate/ predict clinical behaviors based on complex gene expression patterns. This review highlights some of these gene expression signatures and their potential for clinical application in personalized breast cancer medicine. A comprehensive review of gene expression signatures identified in breast cancer is beyond the scope of this review. Rather, the molecular signatures discussed herein reflect those that have scientific importance for our understanding of diversity among breast cancers and molecular signatures that have found clinical utility as Federal Drug Adminstration (FDA)-approved tests or that have great potential for clinical impact based on research studies.

\section{The Intrinsic Molecular Subtypes within Molecular Classification of Breast Cancer}

Early microarray-based transcriptomic studies used hierarchical clustering to identify subsets of breast cancer using genes whose expression varied across individual cancers, but not between repeated analysis of the same cancer. ${ }^{5,7,10}$ Hierarchical clustering analysis is a method for identification of similarity and dissimilarity among individuals (or breast cancers in this case) based on complex patterns that emerge from large data sets of quantitative traits (such as gene expression patterns). Four major molecular subtypes emerged from these early transcriptomic studies: i) luminal, ii) HER2 enriched, iii) basal like, and iv) normal like. The gene expression patterns that appear to drive these classifications are associated with the expression (or lack of expression) of several major gene families, including ER, ER-related genes, genes associated with cell proliferation, HER2, and genes proximal to HER2 in the amplified region of chromosome $17 \mathrm{q} 12 .^{5,7,10-12}$
The normal-like subtype presents a conundrum as these cancers tend to be associated with poor prognosis and can be either ER positive or ER negative. It has been suggested that the normal-like breast cancers may fail to be appropriately classified into one of the other subtypes because of the presence of excess contaminating normal breast epithelium. ${ }^{12}$ This molecular subtype is frequently reported in gene expression studies, but rarely discussed as a biological entity.

Among the remaining major molecular classifications of breast cancer, the luminal cancers are ER positive, whereas the HER2-enriched and basal-like cancers are ER negative. The luminal breast cancers are routinely subdivided into two (luminal A and luminal B) or three (luminal A, luminal B, and luminal C) groups. ${ }^{10}$ However, subdivision of the luminal breast cancers into luminal A and luminal B appears to be the most robust and reproducible. The distinction between luminal A and luminal B breast cancers is linked to the overexpression of HER2 and proliferation markers, with luminal A breast cancers expressing low levels of proliferation-associated genes and luminal B breast cancers expressing high levels of proliferation-related genes. Emerging from the basal-like breast cancers are two subtypes: basal-like breast cancers and claudin-low breast cancers. ${ }^{13}$ The claudin-low breast cancers are enriched for markers of epithelial-to-mesenchymal transition and stem cell-like and/or tumor-initiating features. ${ }^{13}$

The Cancer Genome Atlas Network published results on comprehensive analyses of gene expression patterns, gene mutations, DNA copy number, DNA methylation, and miRNA expression patterns across a large cohort of approximately 800 breast cancers. ${ }^{14}$ Using multiple platforms for gene expression analysis (including microarrays and next-generation sequencing), The Cancer Genome Atlas Network study reproduced the well-recognized ER-positive and ER-negative molecular subtypes of breast cancer. ${ }^{14}$ Of significance, The Cancer Genome Atlas Network study was able to link other genetic and epigenetic lesions with the molecular subtypes identified through gene expression analyses. For instance, HER2-enriched and basal-like breast cancers display a high rate of somatic mutation in the TP53 tumor suppressor gene ( $72 \%$ to $80 \%$ ), whereas the other breast cancer subtypes exhibit TP53 gene mutations much less frequently (12\% to $29 \%$ ). ${ }^{14}$ Luminal A, luminal B, and HER2-enriched subtypes displayed significant rates of mutation in the PIK3CA gene $(45 \%, 29 \%$, and $39 \%$, respectively), whereas basal-like breast cancers were rarely associated with mutation of this gene $(9 \%) .{ }^{14}$ It is notable that numerous genes (involving at least 177 cancer-associated genes) were mutated in small percentages of cancer ( $>20,000$ nonsilent somatic mutations among 510 breast cancers), but few genes were found to be mutated in $>10 \%$ of breast cancers within or across the molecular subtypes. ${ }^{14}$

Copy number variations (reflecting gene deletions and amplifications) were found to affect numerous genes and gene regions, including amplifications affecting chromosomal regions that harbor PIK3CA and ERBB2 and deletions 
in chromosomal regions that harbor TP53 and MAP2K4, among others. ${ }^{14}$ Cancer-associated alterations in DNA methylation include global hypomethylation and genespecific hypermethylation, and evidence suggests that these epigenetic mechanisms play a major role in breast carcinogenesis. ${ }^{15-22}$ Genes that are silenced through DNA hypermethylation in breast cancer include cell cycle control genes $\left(p 16^{I N K 4 a}\right)$, steroid receptor genes (ESRl, PGR, and $R A R B)$, tumor suppressor genes (BRCAl), genes associated with cancer metastasis (CDHI and TIMP3), and many others. ${ }^{23-27}$ Loss of expression of ER is frequently associated with hypermethylation of the ESRl gene. ${ }^{28,29}$ These genetic and epigenetic alterations occurring in breast cancer significantly affect gene expression signatures and contribute to the abnormal biology and clinical behavior (including responses to therapy) of breast cancers in individual patients.

\section{Prognostic and Predictive Signatures}

Numerous molecular signatures have been developed since the advent of microarrays enabled examination of expression of thousands of genes in parallel. Many of these molecular signatures have utility for prediction of breast cancer clinical behaviors (risk of recurrence, response to therapeutics, metastatic potential, and others) and prognostication of long-term patient outcomes (disease-free survival and overall survival). Several excellent reviews are available that describe these molecular signatures in detail. ${ }^{30-36}$

\section{Oncotype DX}

Oncotype DX (Genomic Health, Redwood City, CA) is a 21-gene prognostic and predictor assay based on a continuous variable algorithm that was developed to predict the likelihood of relapse among patients with ER-positive, lymph node-negative, early-stage breast cancer. $^{37-39}$ Oncotype DX has been exempt from FDA clearance, but has been approved by the US Clinical Laboratory Improvement Act as an offering from Genomic Health's central testing laboratory. ${ }^{40}$ The Oncotype DX score ( 0 to 100) provides an indication of relative risk of recurrence within 10 years of breast cancer diagnosis, with higher scores corresponding to greater likelihood of recurrence. The predictive gene expression signature was identified through supervised analysis of microarray data from a pool of 250 candidate genes and 447 breast cancer samples from three clinical trials. ${ }^{37}$ The gene set used is focused on ER pathway genes, proliferation-related genes, and HER2. Of the 21-gene panel, 16 genes are cancer related and the other 5 serve as controls. Higher levels of expression of genes associated with good outcomes (such as ESRI) results in lower recurrence scores, whereas higher levels of expression of genes associated with unfavorable outcomes (including proliferation- and invasion-related genes) result in higher scores. Patients with a recurrence score of $<18$ are classified as low risk, patients with a recurrence score of 18 to 31 are classified as intermediate risk, and patients with a recurrence score of $>31$ are classified as high risk (Figure 1). This molecular assay is applied to patients with early-stage breast cancer in whom the clinicopathological assessment would suggest good prognosis, stratifying the patients who require aggressive therapy (those likely to recur despite other predictive factors) versus those in whom conservative treatment will suffice. In the clinical setting, this molecular assay is often used to stratify risk among patients who are in an intermediate (indeterminate) risk category based on traditional histopathological factors. The assay performs well in identifying those patients with a low potential for cancer recurrence. Oncotype DX does not perform well when applied to patient cohorts that include both ER-positive and ER-negative patients. ${ }^{41}$

Oncotype DX analysis of patients from the NSABP B-20 trial (ER-positive patients with node-negative early-stage breast cancer randomly assigned to receive tamoxifen for 5 years with or without chemotherapy) $)^{42}$ showed that those with a recurrence score $>31$ significantly benefit from the
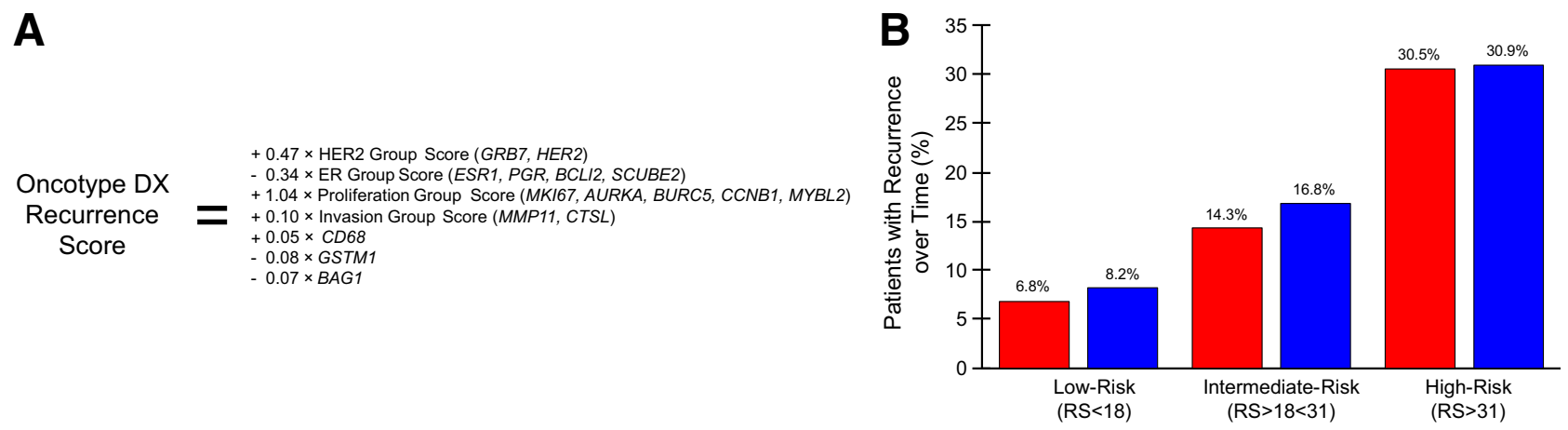

Figure 1 Oncotype DX predicts recurrence among estrogen receptor-positive (ER ${ }^{+}$) early-stage breast cancers. A: The Oncotype DX Recurrence Score (RS) is calculated based on the expression of 16 cancer-associated genes (shown), and 5 control genes (ACTB, GAPDH, RPLPO, GUS, and TFRC). B: Red bars indicate 10-year estimates of distant recurrence for patients with $\mathrm{ER}^{+}$early-stage breast cancers determined by Oncotype DX to have low-, intermediate-, or high-risk disease. Blue bars indicate the actual percentage of $\mathrm{ER}^{+}$early-stage breast cancer patients who developed distant recurrence during the period of follow-up (16 years). The data graphed in B are from Paik et al. ${ }^{37}$ HER2, human epidermal growth factor receptor 2. 
addition of chemotherapy to their treatment regimen. ${ }^{43}$ In contrast, patients with a low recurrence score $(<18)$ showed no benefit from adjuvant chemotherapy. ${ }^{43}$ When Oncotype DX was applied to patients in the Intergroup E2197 trial (which included early-stage breast cancers with up to three positive lymph nodes) ${ }^{44}$ the recurrence score was found to be a significant predictor of recurrence among both nodenegative and node-positive patients with ER-positive disease. ${ }^{45}$ Further validation of the relative value of Oncotype DX emerged from the initial results of the prospective TAILORx trial. ${ }^{46}$ In this study, node-negative patients with ERpositive/HER2-negative breast cancer with a low recurrence score who were treated with hormone therapy alone for 5 years demonstrated excellent overall survival (98\%), and extremely low rates of development of invasive disease $(<7 \%)$ or locoregional/distant recurrence $(<2 \%) .{ }^{46}$ Although Oncotype DX testing only confers benefit to a subset of breast cancer patients (those with ER-positive early-stage disease), among these patients the assay has important clinical utility, identifying those patients who do not require chemotherapy, but will thrive with hormone therapy alone.

Ductal carcinoma in situ (DCIS) of the breast is a common diagnosis among women that presents a dilemma for the clinician regarding likelihood of recurrence or progression to invasive breast cancer. A multigene recurrence score assay was developed based on the Oncotype DX molecular assay. ${ }^{47}$ Oncotype DX DCIS consists of 12 genes, 7 cancerrelated genes (MKI67, AURKA, BIRC5, CCNB1, MYBL2, $P G R$, and GSTM1) and 5 control genes. ${ }^{47}$ Patients from the Eastern Cooperative Oncology Group E5194 study $(n=327)$, who were treated with surgical excision without adjuvant radiation therapy, were evaluated using Oncotype DX DCIS to determine risk of an ipsilateral breast event (local recurrence of DCIS or invasive cancer). Oncotype DX DCIS stratified patients into low-, intermediate-, and highrisk groups, and these groups demonstrated a 10-year risk of DCIS recurrence of $10 \%, 27 \%$, and $25 \%$, respectively, and a 10 -year risk for invasive cancer of $4 \%, 12 \%$, and $19 \%$, respectively. ${ }^{47}$ A more recent retrospective study demonstrated the utility of the Oncotype DX DCIS score for guiding decisions in DCIS patients related to adjuvant radiation therapy. ${ }^{48}$

\section{MammaPrint}

MammaPrint (Agendia, Amsterdam, the Netherlands) is a microarray-based prognostic test for breast cancer patients who are ER positive or ER negative, lymph node negative (stage I or II), and $<61$ years. ${ }^{49}$ This assay was approved by the FDA in 2007 (FDA submission K101454, K081092, K080252, and K070675), and has also been cleared for use by the European Union. MammaPrint examines the expression of 70 genes enabling patients to be stratified into low- and high-risk prognostic groups ${ }^{50,51}$ on the basis of a gene expression score. ${ }^{49,52}$ Patients at high risk for metastasis based on Mammaprint are recommended for aggressive chemotherapy, whereas those with a lower score will receive more conservative therapy.

The 70-gene panel used in the MammaPrint assay includes genes enriched for proliferation, invasion, metastasis, stromal integrity, and angiogenesis, but does not include ESR 1, PGR, or HER $2 .{ }^{30}$ The assay was originally developed using fresh-frozen breast cancer tissues, but more recent developments have adapted this assay to use RNA from formalin-fixed, paraffin-embedded tissues as well. The 70gene prognostic signature was identified from a pool of 25,000 candidate genes that were examined in 78 patients ( $<55$ years old) with early-stage node-negative breast cancer $(<5 \mathrm{~cm}) .{ }^{53}$ In this training set, patients were classified as low risk if they had a high probability of no metastatic disease within 5 years of diagnosis and were classified as high risk if they had a high probability of developing metastatic disease within 5 years of diagnosis. ${ }^{53}$

The MammaPrint assay was validated using a cohort of 295 patients with or without lymph node involvement, identifying 115 patients with a good prognosis signature $(94 \%$ survival at 10 years of follow-up) and 180 patients with a poor prognosis signature (54\% survival at 10 years of follow-up) ${ }^{54}$ These results were further validated in the analysis of 307 patients from the TRANSBIG consortium. ${ }^{52}$ Prospective validation of the MammaPrint assay was first accomplished as part of the RASTER study in 427 patients with node-negative breast cancer. ${ }^{55}$ In this study, MammaPrint outperformed standard clinical and pathologic assessment of breast cancers in the identification of patients who do not benefit from adjuvant chemotherapy based on 10 years of patient follow-up for disease recurrence or progression. ${ }^{55,56}$ In addition, MammaPrint has been shown to identify patients with early-stage breast cancer who will benefit from adjuvant chemotherapy (based on 10 years of follow-up). ${ }^{57}$

\section{PAM50/Prosigna}

The Prediction Analysis of Microarrays (PAM) 50 assay uses a panel of 50 genes (plus five control genes) to generate a risk of recurrence score and classify breast cancers according to the four major intrinsic breast cancer subtypes: luminal A, luminal B, HER2 enriched, and basal like. ${ }^{12}$ This assay was developed using 189 breast cancers of known intrinsic molecular subtype and 1906 intrinsic genes for the training set analysis. The genes selected for this assay were derived from microarray analyses, but then transitioned to a real-time PCR assay. Studies have shown that quantitative PCR methods can be used to reproduce molecular classifications associated with microarray studies. ${ }^{58}$ A group of 161 genes emerged that could be analyzed in formalin-fixed, paraffin-embedded tissues, and this gene set was subjected to reduction to arrive at a 50-gene panel with utility for identification of the four major intrinsic molecular subtypes (Figure 2). Gene expression results from this 50 -gene panel were analyzed using PAM to identify patients at low, intermediate, or high risk for recurrence. ${ }^{12}$ Low-risk disease 
was only identified among ER-positive/HER2-negative (luminal A) breast cancers. ${ }^{12}$ When PAM50 was combined with histological grade, there was significant improvement in prediction of outcome compared to intrinsic molecular subtyping alone or histopathological analysis alone. Furthermore, the PAM50 assay exhibits 94\% sensitivity and $97 \%$ negative predictive value for identifying nonresponders to neoadjuvant chemotherapy, ${ }^{12}$ using data from Hess et al. ${ }^{59}$ Subsequent studies validated the predictive power of the PAM50 assay for breast cancer patient outcomes, ${ }^{60-62}$ particularly in ER-positive breast cancers treated with hormone therapies. . $^{6,64}$

Prosigna (NanoString Technologies, Seattle, WA) is a prognostic molecular signature test that is based on the PAM50 panel of genes. ${ }^{65}$ This assay was approved by the FDA in 2013 (FDA submission K130010), and has also been cleared for use by the European Union. Prosigna is approved to estimate recurrence-free survival among postmenopausal women with stage I/II ER-positive breast cancers treated with adjuvant hormone therapy. This molecular assay is available

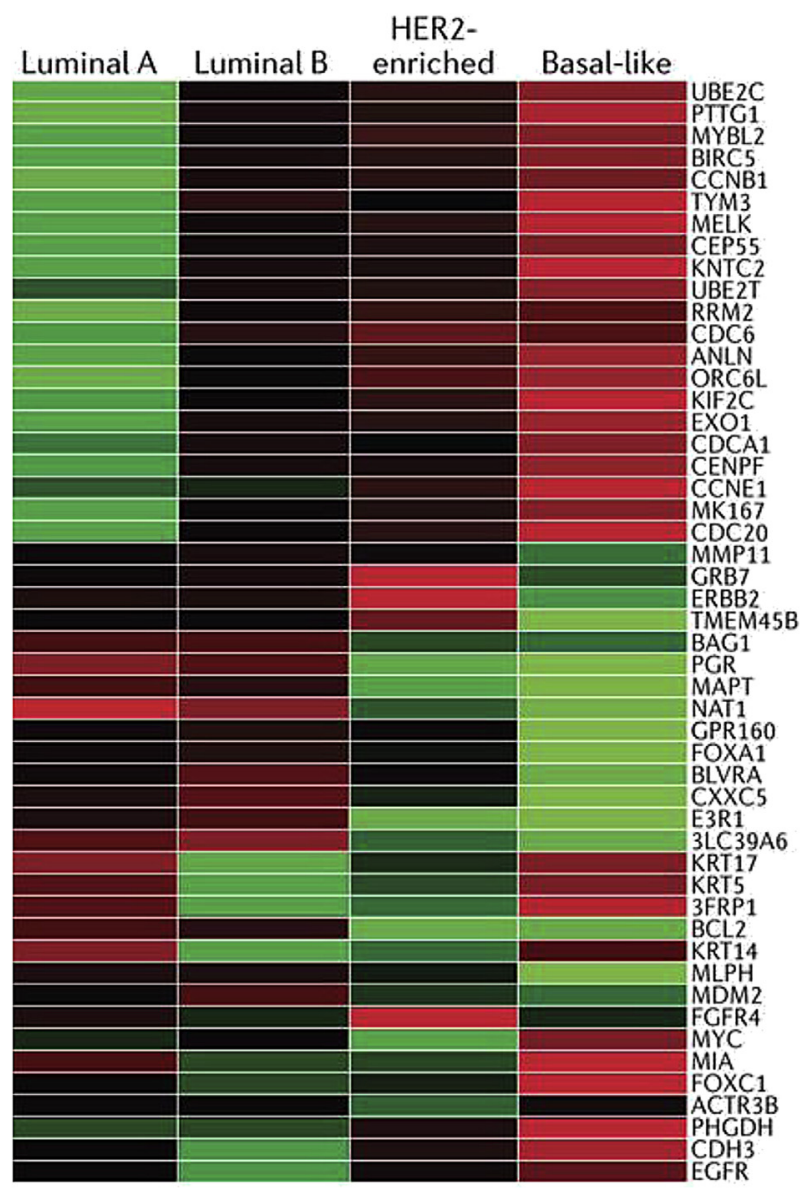

Figure 2 Prediction Analysis of Microarrays (PAM) 50/Prosigna molecular signature. The PAM50 assay quantifies the expression of 50 classifier genes and 5 reference genes to categorize breast cancers into one of four intrinsic biological subtypes [luminal A, luminal B, human epidermal growth factor receptor 2 (HER2) enriched, and basal like]. This figure was adapted from Kwa et $\mathrm{al}^{36}$ with permission from Nature Publishing Group. in clinical laboratories that are equipped with the NanoString nCounter Dx Analysis System (NanoString Technologies, Seattle, WA). Validation studies have demonstrated that Prosigna is robust and reproducible across multiple clinical laboratory settings. ${ }^{66}$ The risk of recurrence scores produced using Prosigna range from 0 to 100, enabling assignment of individual patients into low-, intermediate-, and high-risk categories that reflect 10 -year risk of breast cancer recurrence at distant sites. Hence, the risk of recurrence score generated from the Prosigna molecular assay has clinical utility for identifying which early-stage ER-positive breast cancer patients will benefit from specific therapeutic interventions, including hormone therapy and chemotherapy. Recently, Prat et $\mathrm{al}^{67}$ adapted the PAM50/Prosigna assay to generate a chemoendocrine score that stratifies patients according to the probability of benefit of endocrine therapy versus chemotherapy. This study found that the Prosigna lowrisk group generally corresponded to the chemoendocrine score-endocrine sensitive group, and the Prosigna high-risk group generally corresponded to the chemoendocrine scorechemotherapy sensitive group. ${ }^{67}$ However, the chemoendocrine score exhibits utility for stratifying Prosigna intermediate-risk patients into appropriate treatment cohorts. ${ }^{67}$

\section{The Breast Cancer Index/Breast Cancer Gene Expression Ratio Assay}

The Breast Cancer Index is a PCR-based gene expression analysis assay that was developed to identify patients with early-stage ER-positive breast cancer with a high risk of recurrence after hormone therapy. ${ }^{68}$ This assay generates an index value reflecting the ratio of expression of HoxB13 (encoding Homeobox protein B13) and $I L 17 B R$ (encoding IL-17 receptor B). ${ }^{68}$ The HoxB13/IL17BR ratio is used in conjunction with measures of five proliferation-related genes (which compose the molecular grade index) ${ }^{69,70}$ to give the Breast Cancer Index score. The commercial assay produced by Biotheranostics (San Diego, CA) has not been FDA approved. This assay predicts early $(<5$ years) and late ( $>5$ years) distant recurrence and provides an indication of the likely benefit of extended hormonal therapy. The Breast Cancer Index is particularly useful in the identification of patients at high risk for late recurrence who would benefit from long-term hormone therapy. ${ }^{33}$

\section{EndoPredict}

The EndoPredict assay is a PCR-based test that examines expression of eight cancer-associated genes and three control genes to generate a risk score. The EndoPredict score stratifies patients with ER-positive breast cancer into low or high risk of recurrence group after hormone therapy alone. ${ }^{71}$ EndoPredict is approved for clinical use in Europe and is marketed by Sividon Diagnostics GmbH (Koln, Germany), but has not been FDA approved. EndoPredict has been modified to incorporate node status and tumor size for 
improved prediction, ${ }^{72,73}$ and has utility in prediction of late recurrence. $^{74}$

\section{Other Molecular Signatures}

Numerous other molecular signatures of breast cancer have been developed, but many of these have not been refined or widely applied since their first description. With further development, some of these signatures may find utility in prediction of breast cancer biology and clinical behavior, and prediction of patient responses to therapy and long-term outcomes.

The p53 status signature is a microarray-based assay that examines 747 genes whose expression correlates with TP53 mutation status (mutant versus wild type). ${ }^{75}$ Some studies have shown that breast cancers with a TP53-mutant gene expression signature display resistance to chemotherapy and poor overall prognosis, and so this signature may be useful in further stratifying subsets of breast cancer patients who require aggressive clinical intervention. ${ }^{76,77}$

The estrogen response signature is a microarray-based signature that examines 822 genes that are associated with response to estrogen stimulation and provides a measure for the intactness for the estrogen signaling pathways. ${ }^{78}$ Some studies have shown that the expression of the estrogen response signature is superior to immunohistochemical measures of ER positivity for prediction of responses to hormonal therapies, and that the lack of the estrogen response signature predicts failure of hormone therapy irrespective of immunohistochemical measures of ER positivity. $^{79-81}$ Hence, the estrogen response signature may find clinical utility for further stratification of ER-positive patients for hormone treatment.

The Genomic Grade Index (MapQuant Dx, Ipsogen, Marseilles, France) is a microarray-based assay that examines the expression of 97 genes associated with breast cancer differentiation and grade. ${ }^{82}$ The Genomic Grade Index outperforms traditional histological grade-based methods for prediction of recurrence-free survival, ${ }^{82}$ and predicts responses to chemotherapy. ${ }^{83}$ The Veridex 76-gene signature is a microarray-based assay that examines expression of 76 genes to identify patients with ER-positive node-negative breast cancer who will benefit from adjuvant tamoxifen therapy. ${ }^{84}$ The Veridex 76-gene signature was developed in a manner that is similar to other molecular tests for risk stratification among ER-positive patients. Several groups have identified gene expression signatures associated with a wound response, ${ }^{85,86}$ and have linked this gene expression profile to breast cancer tissue microenvironment $^{85}$ and breast cancer survival. ${ }^{87}$

\section{Future Perspectives}

The first gene expression signatures were developed using microarray technology, and proved useful in prediction of clinical characteristics and survival among breast cancer patients. Useful gene expression signatures have often been large (many genes) on initial development, but are reduced in size on refinement. With smaller gene expression panels, some of these signatures have migrated to PCR-based methods for expression analysis. With the advent of nextgeneration sequencing, we can expect that many of these signatures will eventually be mined from RNA-sequencing data. With further investigation, these gene expression signatures will become both practical (accessible to clinical laboratories in most medical centers) and useful in patient management. In most cases, gene expression signatures have not proved useful in ER-negative breast cancers because of their overall poor survival (reflecting the lack of effective treatments to generate good prognosis cohorts). As targeted therapies are developed and find clinical utility among subsets of breast cancer patients, we can expect development of new gene expression signatures for prediction of responses to specific therapeutic regimens. Furthermore, as RNA sequencing (and similar technologies) is implemented at more cancer treatment centers (and/or in centralized laboratories), the ability to mine the data to extract multiple or many gene expression signatures for an individual patient will enable combined use of panels of molecular signature tests for comprehensive workup of breast cancer patients at the time of diagnosis. With the deployment of multimolecular signature test panels, the manner in which treatment planning occurs will advance and long-term patient outcomes will possibly improve as more efficacious therapeutic strategies are used as first-line treatments in breast cancer patients.

\section{References}

1. Rosen PP: The pathological classification of human mammary carcinoma: past, present and future. Ann Clin Lab Sci 1979, 9:144-156

2. van Bogaert LJ: Recent progress in the histological typing of human breast tumours. Diagn Histopathol 1981, 4:349-353

3. Hariri N, Hasteh F, Walavalkar V, Roma AA, Fadare O: Estrogen receptor, progesterone receptor, and human epidermal growth factor receptor- 2 testing in breast cancer: assessing the value of repeated centralized testing in excision specimens. Appl Immunohistochem Mol Morphol 2017, [Epub ahead of print] doi:10.1097/PAI. 0000000000000525

4. Perou CM, Jeffrey SS, van de Rijn M, Rees CA, Eisen MB, Ross DT, Pergamenschikov A, Williams CF, Zhu SX, Lee JC, Lashkari D, Shalon D, Brown PO, Botstein D: Distinctive gene expression patterns in human mammary epithelial cells and breast cancers. Proc Nat Acad Sci U S A 1999, 96:9212-9217

5. Perou CM, Sorlie T, Eisen MB, van de Rijn M, Jeffrey SS, Rees CA, Pollack JR, Ross DT, Johnsen H, Akslen LA, Fluge O, Pergamenschikov A, Williams C, Zhu SX, Lonning PE, BorresenDale AL, Brown PO, Botstein D: Molecular portraits of human breast tumours. Nature 2000, 406:747-752

6. Ross DT, Scherf U, Eisen MB, Perou CM, Rees C, Spellman P, Iyer V, Jeffrey SS, Van de Rijn M, Waltham M, Pergamenschikov A, Lee JC, Lashkari D, Shalon D, Myers TG, Weinstein JN, Botstein D, Brown PO: Systematic variation in gene expression patterns in human cancer cell lines. Nat Genet 2000, 24:227-235

7. Sorlie T, Perou CM, Tibshirani R, Aas T, Geisler S, Johnsen H, Hastie T, Eisen MB, van de Rijn M, Jeffrey SS, Thorsen T, Quist H, 
Matese JC, Brown PO, Botstein D, Lonning PE, Borresen-Dale AL: Gene expression patterns of breast carcinomas distinguish tumor subclasses with clinical implications. Proc Natl Acad Sci U S A 2001, 98:10869-10874

8. Chung $\mathrm{CH}$, Bernard PS, Perou CM: Molecular portraits and the family tree of cancer. Nat Genet 2002, 32:533-540

9. Rouzier R, Perou CM, Symmans WF, Ibrahim N, Cristofanilli M, Anderson K, Hess KR, Stec J, Ayers M, Wagner P, Morandi P, Fan C, Rabiul I, Ross JS, Hortobagyi GN, Pusztai L: Breast cancer molecular subtypes respond differently to preoperative chemotherapy. Clin Cancer Res 2005, 11:5678-5685

10. Sorlie T, Tibshirani R, Parker J, Hastie T, Marron JS, Nobel A, Deng S, Johnsen H, Pesich R, Geisler S, Demeter J, Perou CM, Lonning PE, Brown PO, Borresen-Dale AL, Botstein D: Repeated observation of breast tumor subtypes in independent gene expression data sets. Proc Natl Acad Sci U S A 2003, 100: $8418-8423$

11. Hu Z, Fan C, Oh DS, Marron JS, He X, Qaqish BF, Livasy C, Carey LA, Reynolds E, Dressler L, Nobel A, Parker J, Ewend MG, Sawyer LR, Wu J, Liu Y, Nanda R, Tretiakova M, Ruiz Orrico A, Dreher D, Palazzo JP, Perreard L, Nelson E, Mone M, Hansen H, Mullins M, Quackenbush JF, Ellis MJ, Olopade OI, Bernard PS, Perou CM: The molecular portraits of breast tumors are conserved across microarray platforms. BMC Genomics 2006, 7:96

12. Parker JS, Mullins M, Cheang MC, Leung S, Voduc D, Vickery T, Davies S, Fauron C, He X, Hu Z, Quackenbush JF, Stijleman IJ, Palazzo J, Marron JS, Nobel AB, Mardis E, Nielsen TO, Ellis MJ, Perou CM, Bernard PS: Supervised risk predictor of breast cancer based on intrinsic subtypes. J Clin Oncol 2009, 27:1160-1167

13. Prat A, Parker JS, Karginova O, Fan C, Livasy C, Herschkowitz JI, He X, Perou CM: Phenotypic and molecular characterization of the claudin-low intrinsic subtype of breast cancer. Breast Cancer Res 2010, 12:R68

14. The Cancer Genome Atlas Network: Comprehensive molecular portraits of human breast tumours. Nature 2012, 490:61-70

15. Bae YK, Brown A, Garrett E, Bornman D, Fackler MJ, Sukumar S, Herman JG, Gabrielson E: Hypermethylation in histologically distinct classes of breast cancer. Clin Cancer Res 2004, 10:5998-6005

16. Domann FE, Rice JC, Hendrix MJ, Futscher BW: Epigenetic silencing of maspin gene expression in human breast cancers. Int J Cancer 2000, 85:805-810

17. Fackler MJ, McVeigh M, Evron E, Garrett E, Mehrotra J, Polyak K, Sukumar S, Argani P: DNA methylation of RASSF1A, HIN-1, RARbeta, Cyclin D2 and Twist in in situ and invasive lobular breast carcinoma. Int J Cancer 2003, 107:970-975

18. Huang TH, Perry MR, Laux DE: Methylation profiling of CpG islands in human breast cancer cells. Hum Mol Genet 1999, 8:459-470

19. Jhaveri MS, Morrow CS: Methylation-mediated regulation of the glutathione S-transferase P1 gene in human breast cancer cells. Gene 1998, 210:1-7

20. Rivenbark AG, Jones WD, Risher JD, Coleman WB: DNA methylation-dependent epigenetic regulation of gene expression in MCF-7 breast cancer cells. Epigenetics 2006, 1:32-44

21. Rivenbark AG, Livasy CA, Boyd CE, Keppler D, Coleman WB: Methylation-dependent silencing of CST6 in primary human breast tumors and metastatic lesions. Exp Mol Pathol 2007, 83:188-197

22. Rivenbark AG, Jones WD, Coleman WB: DNA methylationdependent silencing of CST6 in human breast cancer cell lines. Lab Invest 2006, 86:1233-1242

23. Yang $X$, Yan L, Davidson NE: DNA methylation in breast cancer. Endocr Relat Cancer 2001, 8:115-127

24. Yan PS, Shi H, Rahmatpanah F, Hsiau TH, Hsiau AH, Leu YW, Liu JC, Huang TH: Differential distribution of DNA methylation within the RASSF1A CpG island in breast cancer. Cancer Res 2003, 63:6178-6186

25. Dammann R, Yang G, Pfeifer GP: Hypermethylation of the cpG island of Ras association domain family 1A (RASSF1A), a putative tumor suppressor gene from the 3p21.3 locus, occurs in a large percentage of human breast cancers. Cancer Res 2001, 61:3105-3109

26. Widschwendter M, Berger J, Muller HM, Zeimet AG, Marth C: Epigenetic downregulation of the retinoic acid receptor-beta2 gene in breast cancer. J Mammary Gland Biol Neoplasia 2001, 6:193-201

27. Widschwendter M, Berger J, Hermann M, Muller HM, Amberger A, Zeschnigk M, Widschwendter A, Abendstein B, Zeimet AG, Daxenbichler G, Marth C: Methylation and silencing of the retinoic acid receptor-beta2 gene in breast cancer. J Natl Cancer Inst 2000, 92: 826-832

28. Lapidus RG, Ferguson AT, Ottaviano YL, Parl FF, Smith HS, Weitzman SA, Baylin SB, Issa JP, Davidson NE: Methylation of estrogen and progesterone receptor gene $5^{\prime} \mathrm{CpG}$ islands correlates with lack of estrogen and progesterone receptor gene expression in breast tumors. Clin Cancer Res 1996, 2:805-810

29. Ottaviano YL, Issa JP, Parl FF, Smith HS, Baylin SB, Davidson NE: Methylation of the estrogen receptor gene $\mathrm{CpG}$ island marks loss of estrogen receptor expression in human breast cancer cells. Cancer Res 1994, 54:2552-2555

30. Ross JS: Multigene classifiers, prognostic factors, and predictors of breast cancer clinical outcome. Adv Anat Pathol 2009, 16:204-215

31. Reis-Filho JS, Pusztai L: Gene expression profiling in breast cancer: classification, prognostication, and prediction. Lancet 2011, 378: $1812-1823$

32. Arpino G, Generali D, Sapino A, Del Mastro L, Frassoldati A, de Laurentis M, Paolo P, Mustacchi G, Cazzaniga M, De Placido S, Conte P, Cappelletti M, Zanoni V, Antonelli A, Martinotti M, Puglisi F, Berruti A, Bottini A, Dogliotti L: Gene expression profiling in breast cancer: a clinical perspective. Breast 2013, 22:109-120

33. Gyorffy B, Hatzis C, Sanft T, Hofstatter E, Aktas B, Pusztai L: Multigene prognostic tests in breast cancer: past, present, future. Breast Cancer Res 2015, 17:11

34. Munkacsy G, Szasz MA, Menyhart O: Gene expression-based prognostic and predictive tools in breast cancer. Breast Cancer 2015, 22:245-252

35. Schmidt M, Thomssen C, Untch M: Intrinsic subtypes of primary breast cancer: gene expression analysis. Oncol Res Treat 2016, 39:102-110

36. Kwa M, Makris A, Esteva FJ: Clinical utility of gene-expression signatures in early stage breast cancer. Nat Rev Clin Oncol 2017, [Epub ahead of print] doi:10.1038/nrclinonc.2017.74

37. Paik S, Shak S, Tang G, Kim C, Baker J, Cronin M, Baehner FL, Walker MG, Watson D, Park T, Hiller W, Fisher ER, Wickerham DL, Bryant J, Wolmark N: A multigene assay to predict recurrence of tamoxifen-treated, node-negative breast cancer. N Engl J Med 2004, 351:2817-2826

38. Cronin M, Sangli C, Liu ML, Pho M, Dutta D, Nguyen A, Jeong J, Wu J, Langone KC, Watson D: Analytical validation of the Oncotype DX genomic diagnostic test for recurrence prognosis and therapeutic response prediction in node-negative, estrogen receptor-positive breast cancer. Clin Chem 2007, 53:1084-1091

39. Kaklamani V: A genetic signature can predict prognosis and response to therapy in breast cancer: oncotype DX. Expert Rev Mol Diagn 2006, 6:803-809

40. Ross JS: Multigene predictors in early-stage breast cancer: moving in or moving out? Expert Rev Mol Diagn 2008, 8:129-135

41. Esteva FJ, Sahin AA, Cristofanilli M, Coombes K, Lee SJ, Baker J, Cronin M, Walker M, Watson D, Shak S, Hortobagyi GN: Prognostic role of a multigene reverse transcriptase-PCR assay in patients with node-negative breast cancer not receiving adjuvant systemic therapy. Clin Cancer Res 2005, 11:3315-3319

42. Fisher B, Dignam J, Wolmark N, DeCillis A, Emir B, Wickerham DL, Bryant J, Dimitrov NV, Abramson N, Atkins JN, Shibata H, Deschenes L, Margolese RG: Tamoxifen and chemotherapy for lymph node-negative, estrogen receptor-positive breast cancer. J Natl Cancer Inst 1997, 89:1673-1682

43. Paik S, Tang G, Shak S, Kim C, Baker J, Kim W, Cronin M, Baehner FL, Watson D, Bryant J, Costantino JP, Geyer CE Jr, 
Wickerham DL, Wolmark N: Gene expression and benefit of chemotherapy in women with node-negative, estrogen receptorpositive breast cancer. J Clin Oncol 2006, 24:3726-3734

44. Goldstein LJ, O’Neill A, Sparano JA, Perez EA, Shulman LN, Martino S, Davidson NE: Concurrent doxorubicin plus docetaxel is not more effective than concurrent doxorubicin plus cyclophosphamide in operable breast cancer with 0 to 3 positive axillary nodes: North American Breast Cancer Intergroup Trial E 2197. J Clin Oncol 2008, 26:4092-4099

45. Goldstein LJ, Gray R, Badve S, Childs BH, Yoshizawa C, Rowley S, Shak S, Baehner FL, Ravdin PM, Davidson NE, Sledge GW Jr, Perez EA, Shulman LN, Martino S, Sparano JA: Prognostic utility of the 21-gene assay in hormone receptor-positive operable breast cancer compared with classical clinicopathologic features. J Clin Oncol 2008, 26:4063-4071

46. Sparano JA, Gray RJ, Makower DF, Pritchard KI, Albain KS, Hayes DF, Geyer CE Jr, Dees EC, Perez EA, Olson JA Jr, Zujewski J, Lively T, Badve SS, Saphner TJ, Wagner LI, Whelan TJ, Ellis MJ, Paik S, Wood WC, Ravdin P, Keane MM, Gomez Moreno HL, Reddy PS, Goggins TF, Mayer IA, Brufsky AM, Toppmeyer DL, Kaklamani VG, Atkins JN, Berenberg JL, Sledge GW: Prospective validation of a 21-gene expression assay in breast cancer. $\mathrm{N}$ Engl $\mathrm{J}$ Med 2015, 373:2005-2014

47. Solin LJ, Gray R, Baehner FL, Butler SM, Hughes LL, Yoshizawa C, Cherbavaz DB, Shak S, Page DL, Sledge GW Jr, Davidson NE, Ingle JN, Perez EA, Wood WC, Sparano JA, Badve S: A multigene expression assay to predict local recurrence risk for ductal carcinoma in situ of the breast. J Natl Cancer Inst 2013, 105:701-710

48. Alvarado M, Carter DL, Guenther JM, Hagans J, Lei RY, Leonard CE, Manders J, Sing AP, Broder MS, Cherepanov D, Chang E, Eagan M, Hsiao W, Schultz MJ: The impact of genomic testing on the recommendation for radiation therapy in patients with ductal carcinoma in situ: a prospective clinical utility assessment of the 12-gene DCIS score. J Surg Oncol 2015, 111:935-940

49. Glas AM, Floore A, Delahaye LJ, Witteveen AT, Pover RC, Bakx N, Lahti-Domenici JS, Bruinsma TJ, Warmoes MO, Bernards R, Wessels LF, Van't Veer LJ: Converting a breast cancer microarray signature into a high-throughput diagnostic test. BMC Genomics 2006, 7:278

50. Mook S, Schmidt MK, Viale G, Pruneri G, Eekhout I, Floore A, Glas AM, Bogaerts J, Cardoso F, Piccart-Gebhart MJ, Rutgers ET, Van't Veer LJ; TRANSBIG Consortium: The 70-gene prognosissignature predicts disease outcome in breast cancer patients with 13 positive lymph nodes in an independent validation study. Breast Cancer Res Treat 2009, 116:295-302

51. Bedard PL, Mook S, Piccart-Gebhart MJ, Rutgers ET, Van't Veer LJ, Cardoso F: MammaPrint 70-gene profile quantifies the likelihood of recurrence for early breast cancer. Expert Opin Med Diagn 2009, 3: 193-205

52. Buyse M, Loi S, van’t Veer L, Viale G, Delorenzi M, Glas AM, d'Assignie MS, Bergh J, Lidereau R, Ellis P, Harris A, Bogaerts J, Therasse P, Floore A, Amakrane M, Piette F, Rutgers E, Sotiriou C, Cardoso F, Piccart MJ; TRANSBIG Consortium: Validation and clinical utility of a 70-gene prognostic signature for women with node-negative breast cancer. J Natl Cancer Inst 2006, 98: $1183-1192$

53. van 't Veer LJ, Dai H, van de Vijver MJ, He YD, Hart AA, Mao M, Peterse HL, van der Kooy K, Marton MJ, Witteveen AT, Schreiber GJ, Kerkhoven RM, Roberts C, Linsley PS, Bernards R, Friend SH: Gene expression profiling predicts clinical outcome of breast cancer. Nature 2002, 415:530-536

54. van de Vijver MJ, He YD, van't Veer LJ, Dai H, Hart AA, Voskuil DW, Schreiber GJ, Peterse JL, Roberts C, Marton MJ, Parrish M, Atsma D, Witteveen A, Glas A, Delahaye L, van der Velde T, Bartelink H, Rodenhuis S, Rutgers ET, Friend SH, Bernards R: A gene-expression signature as a predictor of survival in breast cancer. N Engl J Med 2002, 347:1999-2009
55. Drukker CA, Bueno-de-Mesquita JM, Retel VP, van Harten WH, van Tinteren H, Wesseling J, Roumen RM, Knauer M, van 't Veer LJ, Sonke GS, Rutgers EJ, van de Vijver MJ, Linn SC: A prospective evaluation of a breast cancer prognosis signature in the observational RASTER study. Int J Cancer 2013, 133:929-936

56. Drukker CA, Nijenhuis MV, Bueno-de-Mesquita JM, Retel VP, van Harten WH, van Tinteren H, Wesseling J, Schmidt MK, Van't Veer LJ, Sonke GS, Rutgers EJ, van de Vijver MJ, Linn SC: Optimized outcome prediction in breast cancer by combining the 70-gene signature with clinical risk prediction algorithms. Breast Cancer Res Treat 2014, 145:697-705

57. Knauer M, Mook S, Rutgers EJ, Bender RA, Hauptmann M, van de Vijver MJ, Koornstra RH, Bueno-de-Mesquita JM, Linn SC, van 't Veer LJ: The predictive value of the 70-gene signature for adjuvant chemotherapy in early breast cancer. Breast Cancer Res Treat 2010, 120:655-661

58. Perreard L, Fan C, Quackenbush JF, Mullins M, Gauthier NP, Nelson E, Mone M, Hansen H, Buys SS, Rasmussen K, Orrico AR, Dreher D, Walters R, Parker J, Hu Z, He X, Palazzo JP, Olopade OI, Szabo A, Perou CM, Bernard PS: Classification and risk stratification of invasive breast carcinomas using a real-time quantitative RT-PCR assay. Breast Cancer Res 2006, 8:R23

59. Hess KR, Anderson K, Symmans WF, Valero V, Ibrahim N, Mejia JA, Booser D, Theriault RL, Buzdar AU, Dempsey PJ, Rouzier R, Sneige N, Ross JS, Vidaurre T, Gomez HL, Hortobagyi GN, Pusztai L: Pharmacogenomic predictor of sensitivity to preoperative chemotherapy with paclitaxel and fluorouracil, doxorubicin, and cyclophosphamide in breast cancer. J Clin Oncol 2006, 24:4236-4244

60. Cheang MC, Voduc KD, Tu D, Jiang S, Leung S, Chia SK, Shepherd LE, Levine MN, Pritchard KI, Davies S, Stijleman IJ, Davis C, Ebbert MT, Parker JS, Ellis MJ, Bernard PS, Perou CM, Nielsen TO: Responsiveness of intrinsic subtypes to adjuvant anthracycline substitution in the NCIC.CTG MA.5 randomized trial. Clin Cancer Res 2012, 18:2402-2412

61. Chia SK, Bramwell VH, Tu D, Shepherd LE, Jiang S, Vickery T, Mardis E, Leung S, Ung K, Pritchard KI, Parker JS, Bernard PS, Perou CM, Ellis MJ, Nielsen TO: A 50-gene intrinsic subtype classifier for prognosis and prediction of benefit from adjuvant tamoxifen. Clin Cancer Res 2012, 18:4465-4472

62. Martin M, Prat A, Rodriguez-Lescure A, Caballero R, Ebbert MT, Munarriz B, Ruiz-Borrego M, Bastien RR, Crespo C, Davis C, Rodriguez CA, Lopez-Vega JM, Furio V, Garcia AM, Casas M, Ellis MJ, Berry DA, Pitcher BN, Harris L, Ruiz A, Winer E, Hudis C, Stijleman IJ, Tuck DP, Carrasco E, Perou CM, Bernard PS: PAM50 proliferation score as a predictor of weekly paclitaxel benefit in breast cancer. Breast Cancer Res Treat 2013, 138:457-466

63. Filipits M, Nielsen TO, Rudas M, Greil R, Stoger H, Jakesz R, BagoHorvath Z, Dietze O, Regitnig P, Gruber-Rossipal C, MullerHolzner E, Singer CF, Mlineritsch B, Dubsky P, Bauernhofer T, Hubalek M, Knauer M, Trapl H, Fesl C, Schaper C, Ferree S, Liu S, Cowens JW, Gnant M; Austrian Breast and Colorectal Cancer Study Group: The PAM50 risk-of-recurrence score predicts risk for late distant recurrence after endocrine therapy in postmenopausal women with endocrine-responsive early breast cancer. Clin Cancer Res 2014, 20:1298-1305

64. Gnant M, Filipits M, Greil R, Stoeger H, Rudas M, Bago-Horvath Z, Mlineritsch B, Kwasny W, Knauer M, Singer C, Jakesz R, Dubsky P, Fitzal F, Bartsch R, Steger G, Balic M, Ressler S, Cowens JW, Storhoff J, Ferree S, Schaper C, Liu S, Fesl C, Nielsen TO; Austrian Breast and Colorectal Cancer Study Group: Predicting distant recurrence in receptor-positive breast cancer patients with limited clinicopathological risk: using the PAM50 Risk of Recurrence score in 1478 postmenopausal patients of the ABCSG- 8 trial treated with adjuvant endocrine therapy alone. Ann Oncol 2014, 25:339-345

65. Wallden B, Storhoff J, Nielsen T, Dowidar N, Schaper C, Ferree S, Liu S, Leung S, Geiss G, Snider J, Vickery T, Davies SR, Mardis ER, 
Gnant M, Sestak I, Ellis MJ, Perou CM, Bernard PS, Parker JS: Development and verification of the PAM50-based Prosigna breast cancer gene signature assay. BMC Med Genomics 2015, 8:54

66. Nielsen T, Wallden B, Schaper C, Ferree S, Liu S, Gao D, Barry G, Dowidar N, Maysuria M, Storhoff J: Analytical validation of the PAM50-based Prosigna Breast Cancer Prognostic Gene Signature Assay and nCounter Analysis System using formalinfixed paraffin-embedded breast tumor specimens. BMC Cancer 2014, 14:177

67. Prat A, Lluch A, Turnbull AK, Dunbier AK, Calvo L, Albanell J, de la Haba-Rodriguez J, Arcusa A, Chacon JI, Sanchez-Rovira P, Plazaola A, Munoz M, Pare L, Parker JS, Ribelles N, Jimenez B, Bin Aiderus AA, Caballero R, Adamo B, Dowsett M, Carrasco E, Martin M, Dixon JM, Perou CM, Alba E: A PAM50-based chemoendocrine score for hormone receptor-positive breast cancer with an intermediate risk of relapse. Clin Cancer Res 2017, 23:3035-3044

68. Ma XJ, Wang Z, Ryan PD, Isakoff SJ, Barmettler A, Fuller A, Muir B, Mohapatra G, Salunga R, Tuggle JT, Tran Y, Tran D, Tassin A, Amon P, Wang W, Wang W, Enright E, Stecker K, EstepaSabal E, Smith B, Younger J, Balis U, Michaelson J, Bhan A, Habin K, Baer TM, Brugge J, Haber DA, Erlander MG, Sgroi DC: A two-gene expression ratio predicts clinical outcome in breast cancer patients treated with tamoxifen. Cancer Cell 2004, 5:607-616

69. Jankowitz RC, Cooper K, Erlander MG, Ma XJ, Kesty NC, Li H, Chivukula M, Brufsky A: Prognostic utility of the breast cancer index and comparison to Adjuvant! Online in a clinical case series of early breast cancer. Breast Cancer Res 2011, 13:R98

70. Ma XJ, Salunga R, Dahiya S, Wang W, Carney E, Durbecq V, Harris A, Goss P, Sotiriou C, Erlander M, Sgroi D: A five-gene molecular grade index and HOXB13:IL17BR are complementary prognostic factors in early stage breast cancer. Clin Cancer Res 2008, $14: 2601-2608$

71. Filipits M, Rudas M, Jakesz R, Dubsky P, Fitzal F, Singer CF, Dietze O, Greil R, Jelen A, Sevelda P, Freibauer C, Muller V, Janicke F, Schmidt M, Kolbl H, Rody A, Kaufmann M, Schroth W, Brauch H, Schwab M, Fritz P, Weber KE, Feder IS, Hennig G, Kronenwett R, Gehrmann M, Gnant M; EP Investigators: A new molecular predictor of distant recurrence in ER-positive, HER2negative breast cancer adds independent information to conventional clinical risk factors. Clin Cancer Res 2011, 17:6012-6020

72. Dubsky P, Filipits M, Jakesz R, Rudas M, Singer CF, Greil R, Dietze O, Luisser I, Klug E, Sedivy R, Bachner M, Mayr D, Schmidt M, Gehrmann MC, Petry C, Weber KE, Kronenwett R, Brase JC, Gnant M; Austrian Breast and Colorectal Cancer Study Group: EndoPredict improves the prognostic classification derived from common clinical guidelines in ER-positive, HER2-negative early breast cancer. Ann Oncol 2013, 24:640-647

73. Dubsky P, Brase JC, Jakesz R, Rudas M, Singer CF, Greil R, Dietze O, Luisser I, Klug E, Sedivy R, Bachner M, Mayr D, Schmidt M, Gehrmann MC, Petry C, Weber KE, Fisch K, Kronenwett R, Gnant M, Filipits M; Austrian Breast and Colorectal Cancer Study Group: The EndoPredict score provides prognostic information on late distant metastases in ER+/HER2- breast cancer patients. Br J Cancer 2013, 109:2959-2964

74. Muller BM, Keil E, Lehmann A, Winzer KJ, Richter-Ehrenstein C, Prinzler J, Bangemann N, Reles A, Stadie S, Schoenegg W, Eucker J, Schmidt M, Lippek F, Johrens K, Pahl S, Sinn BV, Budczies J, Dietel M, Denkert C: The EndoPredict gene-expression assay in clinical practice: performance and impact on clinical decisions. PLoS One 2013, 8:e68252
75. Troester MA, Herschkowitz JI, Oh DS, He X, Hoadley KA, Barbier CS, Perou CM: Gene expression patterns associated with p53 status in breast cancer. BMC Cancer 2006, 6:276

76. Coleman WB, Parker JS, Sandhu R, Anders CK: Presence of a p53 mutant gene expression signature associates with poor outcomes among breast cancers. Pathobiology for Investigators, Students, and Academicians [abstract 9.17]. American Society for Investigative Pathology, October 2015

77. Coleman WB, Parker JS, Sandhu R, Anders CK: Expression of a p53 mutant gene expression signature associates with poor outcomes among ER+/PR +/Her2- breast cancers. Pathobiology for Investigators, Students, and Academicians [abstract 9.18]. American Society for Investigative Pathology, October 2015

78. Oh DS, Troester MA, Usary J, Hu Z, He X, Fan C, Wu J, Carey LA, Perou CM: Estrogen-regulated genes predict survival in hormone receptor-positive breast cancers. J Clin Oncol 2006, 24:1656-1664

79. Sandhu R, Parker JS, Anders CK, Coleman WB: Differential responses to hormone therapy among ER+/PR+/HER2- breast cancers that differentially express the estrogen response signature. FASEB J 2015, 29:284.7

80. Sandhu R, Parker JS, Anders CK, Coleman WB: Recurrence-free survival among patients with $\mathrm{ER}+/ \mathrm{PR}+/ \mathrm{HER} 2$ - breast cancers is predicted by expression of the estrogen response signature. FASEB J 2015, 29:926.2

81. Sandhu R, Parker JS, Anders CK, Coleman WB: Therapeutic benefit of chemotherapy and hormone therapy among estrogen response signature-positive ER+/PR+/HER2- breast cancers. FASEB J 2015, 29:926.6

82. Sotiriou C, Wirapati P, Loi S, Harris A, Fox S, Smeds J, Nordgren H, Farmer P, Praz V, Haibe-Kains B, Desmedt C, Larsimont D, Cardoso F, Peterse H, Nuyten D, Buyse M, Van de Vijver MJ, Bergh J, Piccart M, Delorenzi M: Gene expression profiling in breast cancer: understanding the molecular basis of histologic grade to improve prognosis. J Natl Cancer Inst 2006, 98:262-272

83. Liedtke C, Hatzis C, Symmans WF, Desmedt C, Haibe-Kains B, Valero V, Kuerer H, Hortobagyi GN, Piccart-Gebhart M, Sotiriou C, Pusztai L: Genomic grade index is associated with response to chemotherapy in patients with breast cancer. J Clin Oncol 2009, 27: 3185-3191

84. Zhang Y, Sieuwerts AM, McGreevy M, Casey G, Cufer T, Paradiso A, Harbeck N, Span PN, Hicks DG, Crowe J, Tubbs RR, Budd GT, Lyons J, Sweep FC, Schmitt M, Schittulli F, Golouh R, Talantov D, Wang Y, Foekens JA: The 76-gene signature defines high-risk patients that benefit from adjuvant tamoxifen therapy. Breast Cancer Res Treat 2009, 116:303-309

85. Troester MA, Lee MH, Carter M, Fan C, Cowan DW, Perez ER, Pirone JR, Perou CM, Jerry DJ, Schneider SS: Activation of host wound responses in breast cancer microenvironment. Clin Cancer Res 2009, 15:7020-7028

86. Chang HY, Sneddon JB, Alizadeh AA, Sood R, West RB, Montgomery K, Chi JT, van de Rijn M, Botstein D, Brown PO: Gene expression signature of fibroblast serum response predicts human cancer progression: similarities between tumors and wounds. PLoS Biol 2004, 2:E7

87. Chang HY, Nuyten DS, Sneddon JB, Hastie T, Tibshirani R, Sorlie T, Dai H, He YD, van't Veer LJ, Bartelink H, van de Rijn M, Brown PO, van de Vijver MJ: Robustness, scalability, and integration of a wound-response gene expression signature in predicting breast cancer survival. Proc Natl Acad Sci U S A 2005, 102:3738-3743 